\title{
On the 60-ft. Raised Beach at Easington, Co. Durham.
}

\author{
By David Woolacott, D.Sc., F.G.S.
}

(PLATE V.)

$A \mathrm{~N}$ excellent exposure of a Raised Beach has lately been discovered $A$ at Easington. 1 This deposit, in my opinion, forms a part of the beds of sand, gravel, conglomerate, and breccia which are exposed along this part of the Durham coast for at least 5 or 6 miles, and which were described by me as Raised Beaches in $1905 .^{2}$ I also consider that the upraised littoral formations were produced in late Pleistocene times.

All geologists who have examined the exposure-including G. W. Lamplugh, F.R.S., ${ }^{3}$ Dr. Trechmann, ${ }^{4}$ E. Merrick, M.Sc., L. Hawkes, M.Sc--are agreed that it is undoubtedly a littoral formation, and although there may not yet be complete agreement as to the exact age or extent of this deposit, yet there can be no question that it must be taken into account in any discussion of the Glacial and Post-Glacial formations of the East of England. There is nothing very remarkable in Raised Beaches at such a level, nor in the amount or nature of the movements that produced them; their importance lies more in connexion with the origin and method of deposition of a large portion of the sands, gravels, and clays that occur above the truc boulder clay (or moraine profonde of the icesheets)along the coastal region or up the buried Pre-glacial valleys of the east of England than in the deposits or uplifts themselves.

The section has the chief characters we expect to find in such exposures typically preserved, and these can be easily examined. It occurs on the south-east flank of Beacon Hill, about half a mile north of Easington station, and can be clearly seen in a steep footpath (the top of which is marked by a stile) leading down to the shore at this point. The photographs published with this paper give a clear idea of the nature of the deposit, as far as it can be conveyed by photographs; the features proving its direct marine

1 A short description of this deposit was given in the Geologrcal MaGazire, vol. lvii, 1920 , p. 307 .

2 "The Superficial Deposits and Preglacial Valleys of the Northumberland and Durham Coalfield" : Quart. Journ. Geol. Soc., vol. 1xi, 1905, pt. 1, and map, pl. ix, p. 94 .

3 I consider that this geologist, who evidently thoroughly appreciated the importance of the occurrence of high-level Raised Beaches in Durham, was quite justified when he asked me to be cautious in accepting the evidence for their existence (see discussion, Geographical Journal, July, 1907, p. 56).

4 I also think that until the Easington depcsit was discovered, Dr. Trechmann, in speaking of the beds along the coast of South Durham, had complete justifica. tion for stating " that he did not see the necessity for assuming these gravel deposits of marine origin" (Q.J.G.S., vol. Ixxi, pt. i, 1915, p. 75). I had, how. ever, definite evidence in 1900-6 of a Raised Beach at a higher level in northeast Durham, and had made in 1903-4 a detailed examination of the course of conglomerate to the north and south of Easington, which had convinced me of its origin. (I do not think that the path that cuts through the Easington deposit existed at that time.) 
origin are, however, much more striking in the field. It is undoubtedly a bed laid down on the margin of the sea, and is in situ. It has not been carried by ice into the position in which it occurs, nor has it been reassorted since its deposition on the ancient shore.

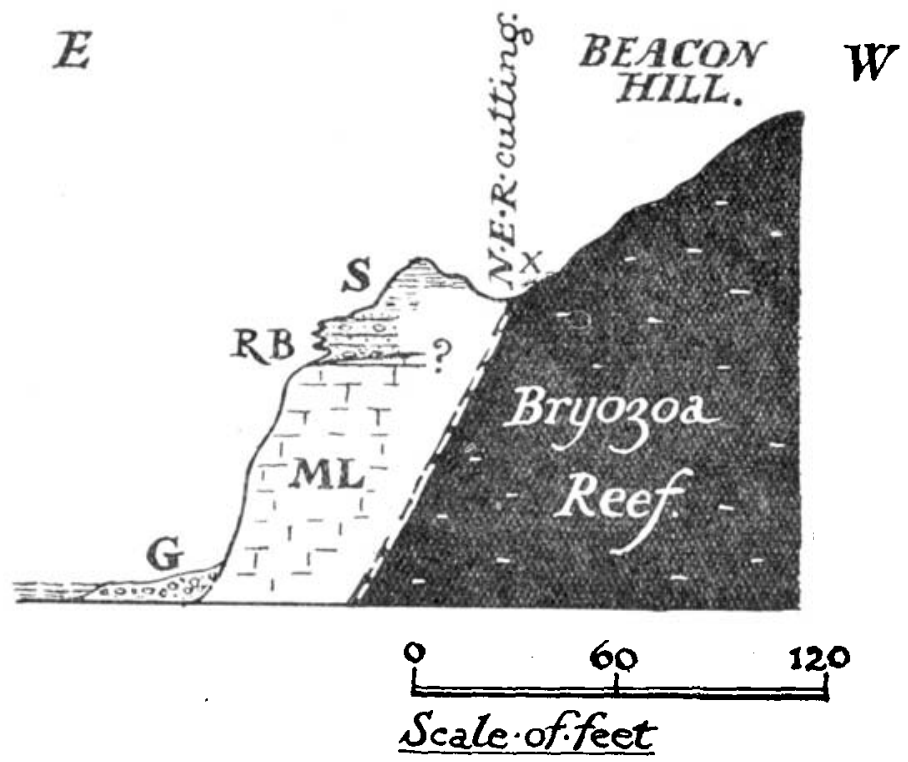

FIa. 1. - Section of the cliff at Easington showing the position of the Raised Beach. M.L. Middle Magnesian limestones and breccias-the eastern equivalents of the fossiliferous Reef which forms Beacon Hill. R.B. The $60 \mathrm{ft}$. Raised Beach resting on the rock-platform, which probably rises slightly as it passes beneath the deposit. S. In a cutting made in the face the calcreted gravels were proved to be 15 feet in thickness, covered by a thin deposit of soft sand with shell fragments, above which was reassorted boulder clay (Common Clay), the whole being covered by washed soil. $\mathrm{X}$. Calcreted gravels in the railway cutting which have a regular upper limit and are probably marine. G. Present-day shingle.

The more interesting features of the deposit are (1) it rests on a horizontal platform of Middle Magnesian Limestone at about 60 feet above sea-level (Figs. 1 and 2). At one part on the south side of the path the shelf has been bored by a small boring organism, and there can be no doubt that it is a real wave-cut terrace. This platform can be distinctly followed both ways (Plate V, Fig. 2), and can be seen to pass in the latter direction from rock on to true boulder clay (Fig. 2), when it becomes less uniform and distinct. ${ }^{1}$ (2) The

1 It is important to notice that the platform must have been cut on boulder clay. This clay is the Main or British Drift of this coast containing Lake District and Cheviot erraties. Even if the Raised Beach is restricted to the narrowest limits, yet the platform must have been cut on boulder clay. 
deposit, which is at least 15 feet thick, ${ }^{1}$ consists of two parts, which are best seen on the north side of the path, a lower one of loose sand and large pebbles, and an upper of horizontally-bedded and firmly-calcreted conglomerate. In the lower layers numerous bored stones occur. It contains, along with other rocks, numerous large and small fragments of Magnesian Limestone, which are bored by Saxicava (the shells of which sometimes occur in the holes), and by Cliona and Polydora. Quite a considerable proportion of this division of the deposit is formed of these bored pebbles. (3) Also in the lower part numerous specimens of small and large, whole and broken, shells occur, sometimes with their colour and markings beautifully preserved. They include many of the common shells of the present seashore--the periwinkle and the limpet, etc.-and as far as the fauna has been examined there is nothing to show that the climate was different from that of the present day. ${ }^{2}$ Foraminifera also occur in the sand. The species of Mollusca occurring in the deposit include :- 3

\begin{tabular}{ll} 
Littorina littorea & Buccinum undatum. \\
Littorina rudis & Cyprina islandica \\
Littorina obtusata & Mytilus edulis. \\
Patella vulgata & Ostrea sp. \\
Purpura lapillus & Rhynchonella psittacea \\
\multicolumn{2}{c}{ Saxicava sp. }
\end{tabular}

The commonest species are Littorina obtusata, Patella vulgata, and Littorina liltorea. It is a typical littoral fauna with the exception of the Rhynchonella, of which one specimen of a dorsal valve has been collected.

In the upper cemented part the shells are scarcer, but some, including one or two whole Pctellas, can be seen in the face of the conglomerate. A portion of the shell of a Pecten was collected from the upper beds. This part of the deposit is more difficult to properly examine. The shelis are not so clearly seen nor so well preserved nor so easily extracted. ${ }^{4}$ The strongly calcreted nature of this conglomerate, and the fact that it contains fewer bored rocks and shells, are of interest, because it is the more usual type of the deposit to the north and south of Easington. The beds at this point appear to have been laid down in a sheltered bay under fairly tranquil

1 About 10 feet can be clearly seen in the section, but its thickness (allowing that the platform runs back horizontally) has been proved by a cutting made in the face above it to be 15 feet. The bedded gravels are this thickness, being overlaid by a few inches of soft sand containing shell fragments, above which is a reassorted boulder clay. Calcreted gravels with a level upper limit can be seen in the railway cutting above at about 90 feet. The writer is of the opinion they are marine, although it is difficult to prove this; it is also uncertain whether they are continuous with the gravels and sands below.

2 A collection of shells from this deposit has been placed in the Sunderland and Newcast]e museums.

3 My determination of the forms has in most cases been verified by

Dr. Trechmann or Mr. Tredale, of the British Muscum.

4 At one part two or three shells of Helix are cemented in. 
conditions, hence the greater accumulation of bored rocks, shells, and shell-fragments, and their more distinctly bedded nature than is usually the case in other exposures of them along the coast. All the features of a typical raised beach appear to be combined here. It is obvious that a great quantity of the Glacial deposits must have been denuded to form these beds, and it thus seems probable that one of the reasons for the unequal distribution of the shells in them is that where the boulder clay was being most eroded the water would be muddy and the life of the shore scarcer, and another is that the beds that are exposed were not always deposited on a rock platform, but on boulder clay, and the accumulations of material in these areas must have been very loose and coarse. In such conditions and in such material whole shells are not likely to be preserved. It is, however, probable that the rock platform is buried beneath and behind the deposits exposed along the coast, and that the raised beach characters would always be more definite on this ledge. (4) The pebbles, of which the conglomerate at the particular point discussed is formed, are generally distinctly waterworn, but some are more or less angular. In it there are fragments of Magnesian Limestone, quartz, quartzite, flint, sandstone, granite, olivine-basalt, Volcanic Series of Borrowdale from the Lake District, and porphyritic lava from the Cheviots. It is perhaps worthy of note that the Cheviot and Lake District rocks occur in the loose, sandy base of the deposit as well as in the calcreted part above. About fifty per cent of the rocks are foreign to the district, and have, in my opinion, been derived from the denudation of the Glacial deposits of the area. There is no evidence that any have been brought to the point by floating ice, but even if it is allowed that some have, yet it is evident that the Firth of Forth, Lake District, and Tweed-Cheviot ice must have been occupying part of the east coast at the time. The writer is of the opinion that the deposit is definitely later than the formation of the Main or British boulder clay. The conglomerate can be followed to the south in an unbroken course along the rock platform on to boulder clay, from the erosion of which it appears to have been in part derived. On the clay the wave-cut shelf becomes less distinct, and the cemented gravels thicken downwards (Fig. 2). The assemblage of stones at Easington, and in the conglomerate to the north and south, is similar to that which is accumulating along the Durham coast at the present day, in places where the cliff is composed of Permian Limestone and boulder clay. (5) The calcreted gravels can be followed in an unbroken course for a considerable distance, and can be traced for some miles. This layer is much more persistent than the platform on which it rests. At several points below the $60-\mathrm{ft}$. level accumulations of fragmental material occur. These were, in $\mathrm{my}$ opinion, formed at the same time as the Raised Beach at Easington. They consist of a series of deposits, varying much in character and coarseness, and are composed of sand, gravel, hard calcreted 
conglomerate, and coarse breccia. The gravels are not usually so distinctly bedded, nor do they appear anywhere to contain so many bored rocks and shells as the typical part of the Easington deposit, but that they were formed under the same conditions, and are raised littoral formations, appears clear when the coast between Seaham Harbour and Castle Eden Dene is critically examined. It is important to notice that the top of the level course can be traced along the cliff for a few miles; this layer marks a period of repose in the movements that raised the beaches. It is a most distinct feature and could only have been so uniformly laid down by marginal deposition. The beds vary considerably, but they always contain the same assemblage of local and foreign rocks, and shell fragments can generally be seen in most exposures when they are examined carefully. The series of sections along this coast is, in my opinion,
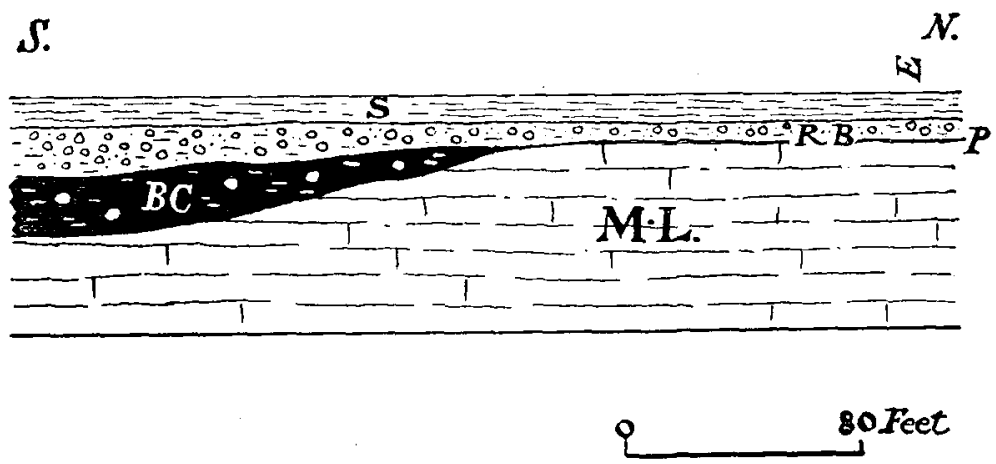

Frr. 2.-Section along the face of the cliff at Easington. M.L. Middle Magnesian Limestone, the eastern equivalents of the Reef. B.C. Main boulder elay with Tweed-Cheviot and Lake District boulders. R.B. Raised Beach resting on rock platform. P. The bedding is most distinct at (but not confined to) the north end, and the platform is less clearly defined when the deposit passes on to clay. S. Deposits of soft shelly sand, brown reassorted boulder clay (Common Clay) rainwash and soil. E. Position of Easington section (Fig. 3). The photographs, Figs. $l$ and 2, are also of the cliff at this point.

that which might be expected under the conditions in which a late Pleistocene beach would be formed, and afterwards upraised. It has been suggested that, although the deposit at Easington is undoubtedly a beach, yet the course of cemented gravels on the same level may be of Fluvio-glacial origin; but the mode of occurrence of these beds is unlike that of material of this type of deposition, which has a tendency to occur in mounds, swellings, and irregular beds, and not in extensive regular courses, except where it has been washed into a lake or the sea. It is also impossible to draw any line between what is undoubtedly a beach and that which is conjectured to be Fluvio-glacial. Another point of interest is that in deciding that a deposit is an uplifted littoral formation, we insist 
that it shall possess certain well-defined characters, such as the Easington deposit so clearly displays; but it is certain that all these features cannot always be found at every point in such formations. If, for example, the present coast of Durham was uplifted, there are few places at which such a tout ensemble of characters as we find at Easington could be seen in the elevated deposits. There are not many stretches of the shore where there are accumulating such a distinctly bedded series of deposits with such an assemblage of shells and bored rocks ; in many parts very few bored pebbles and few whole shells occur in the gravels; the shingle is sometimes not distinctly bedded, and often in front of a limestone cliff a coarse, angular deposit is accumulating (which, if uplifted and cemented, would form a breccia similar to that just referred to). Another feature of marginal deposits, which is often not taken into account, is that for a certain distance below high-water mark there is a zone of erosion and most of the shells are either washed up on shore above it or washed out beyond it, so that parts of uplifted strand deposits may contain few or no shells, because they were formed within this zone.

The peculiar mode of occurrence and other features of the sands, gravels, conglomerates, and breccias along the coast of Mid-Durham (together with the definite evidence of Raised Beaches on Fulwell and Cleadon Hills to the north), impressed me when I first studied this coast many years ago, and convinced me that these deposits were marginal sea-deposits. I have collected shell fragments from. many parts of these beds, but do not remember collecting any perfect shells $\mathbf{1}$ (except at Easington), although I was always expecting to find a typical littoral exposure like that at this place. I have no doubt that other similar exposures will be discovered, especially now it is known where to expect them in these deposits. In my opinion the section described in this paper finally settles that these conglomerates are a true Raised Beach, and also proves that they were formed in late Pleistocene times. I further consider that a wave-cut terrace runs along the Durham coast, on which part of these deposits rest. This level platform, with its bed of cemented gravels, forms a noticeable feature of the coast for some miles. It is specially distinct near Easington and Nose's Point, and to the north of Hawthorn Dene. Mr. Lamplugh has asked me to consider the possibility that the beach at Easington may be local (the rest of the course being Fluvio-glacial), and that it is a remnant of a Pre-glacial or early Glacial strand deposit preserved from removal by the ice that swept southwards along this coast, ${ }^{2}$ while the rest of the deposit was removed; ${ }^{3}$ while, on the other hand, Dr. Trechmann

I I have obtained numerous perfect Littorinas from the higher beach on Fulwell, and some have been found in the Cleadon Sand Pit, etc.

2 "The Interglacial Problem and the Glacial and Post-Glacial sequence in Northumberland and Durham": Geor. MAG., Vol. LVIII, 1921, p. 27.

3 e.g. the Horsebridge Head deposit near Newbiggen, and the Sewerby Raised Beach near Flamborough Head were so preserved. 
has suggested the possibility that it may be the remnant of an Interglacial (or Glaciation-Interval) beach, preserved in a similar way. I am unable to accept either of these hypotheses. The points definitely against them are (1) the fauna is a recent temperate onethere are apparently no species characteristic of Arctic conditions, (2) pebbles of Lake District, Cheviot, and Firth of Forth rocks occur in the deposit, (3) it is not overlaid by true boulder clay but by reassorted boulder clay, (4) it is impossible to isolate the part of of the beds that is allowed by everyone to be a littoral deposit, from that which is conjectured to be Fluvio-glacial, (5) since the top of the course of calcreted gravels is regular and persistent (even if we assume the rest of the beach has been removed by ice) we should have to admit that the Fluvio-glacial beds are forming a kind of pseudomorph of the beach for some miles, and maintaining a uniform level, whether the platform is Magnesian Limestone or boulder clay. It would appear impossible, if the whole of the beach were removed, that the platform of boulder clay would not have been destroyed by the conjectured ice-movement, and highly improbable that the top of the Fluvio-glacial gravels that replaced the beach could always maintain a uniform level for such a long distance.

One of the objections raised some years ago against the occurrence of late-Glacial or Post-glacial Raised Beaches on the Durham coast, was that it had been found impossible to trace them in Yorkshire, ${ }^{1}$ and another that there was a considerable stretch of country to the north from which marine deposits of this age are apparently absent. ${ }^{2}$ One of the causes of this may be that they are in reality late-glacial and that although the Durham littoral was free from ice when they were forming, yet it was still occupying part of the coast of northeast England, while another is that the uplift was not a uniform one. I further think that the great amount of coastal denudation and reassortment of glacial material along the main rivers that has taken place since the end of the Ice Age is not appreciated by all geologists. From parts of the coast (e.g. north-east Yorkshire) the beaches may have been removed by denudation of the superficial deposits that once covered this coast as with a mantle. It is of interest in connexion with this subject that late Pleistocene raised marine shore-lines passing into river terraces do occur up to about 125 feet in the Firths of Forth, Clyde, Tay, and elsewhere in Scotland, ${ }^{3}$ and that an

1 The estuarine leafy clays and well-worn shingle which oceur at Kirmington (Lincolnshire) obviously lessens the force of this argument (see footnote p. 71).

2 Low level beaches ( 30 feet (?) and 10 feet) do occur in North Northumberland, and high level beaches (125 feet) occur in Scotland.

3 In these deposits fossils are scarce, but the shells found in connexion with the higher beds indicate a colder climate than those of the Durham beaches. The fauna includes Pecten greenlandicus, Leda arctica, Tellina myopsis (all Arctic forms) and remains of the small Arctic seal. The lower terrace is associated with clays containing Scrobicularia piperata (which also occurs in the Kirmington deposit), and indicates the incoming of warmer conditions. J. Geikie, Great Ice Age, p. 273, and Geol. Surt. Mem.: "The Neighbourhood of Edinburgh," 1910 , p. 335. 
estuarine deposit, also of somewhat similar age, has been described from Kirmington, in Lincolnshire, at an elevation of $60-80$ feet, ${ }^{1}$ and that there are evidences of late Glacial and Post-glacial uplifts in the Wash ${ }^{2}$ and West Norfolk ${ }^{3}$ and other parts of England.

While the Raised Beach at Easington is in itself of much interest, yet it is, as stated in the beginning of this paper, in connexion with the formation of a considerable part of the upper sands, leafy, stony, stoneless, and prismatic clays that the uplift proved by it (and the higher beach in North Durham) becomes of importance in general Glacial geology. It is clear that much of the material along the east coast of England and up the buried Pre-glacial valleys of the "Tyne" and "Tees"," etc.-which has been considered to be true boulder clay is in reality reassorted clay (both stony and stoneless clays), or which has been conjectured to have been deposited in Glacier-lakes (leafy clays), or which has been thought to be of Fluvio-glacial origin (sand and gravel) - is of estuarine and marine origin, and was formed when the coastal region was embayed near the end of the Glacial period. The scarcity of the fossil remains in the clays and sands of estuarine origin may be partly owing to the turbid nature of the waters brought about by the rapid denudation of the Glacial and Fluvio-glacial deposits, and also to the comparatively short period and to the rather rapid nature of the movements during which they were deposited. It seems obvious that after the retreat of the ice-sheet and the incoming of the sea a marine fauna would be able to establish itself much more quickly than an estuarine or freshwater one in the north of England. Tracks of some form of locomotive life are common on some of the layers of the leafy clays, but no shells have been observed by any geologist. Shells and bored pebbles are reported to have been found in some clays in a brickfield near Harton, but Mr. E. Merrick, who has made a detailed study in the field of the clays of the Tyne and Wear districts, has never found any shells in them, although he has verified the occurrence of the bored pebbles. A molluscan estuarine fauna has not yet been proved to have inhabited the Tyne

1 B.A. Report, Cambridge, 1904, p. 272. In this section there is a deposit of laminated clay with estuarine shells, etc., at about $70-80$ feet above sealevel. It is underlaid by Purple Drift (= Main or British Drift of Durham Coast) and above it is a well-worn beach-shingle, principally of battered flints and a clay with foreign stones. Is this clay a true boulder clay? Is it Hessle clay? If so, it is the equivalent of the Durham Prismatic Clay and other reassorted clays which are not of direct Glacial origin. The Kirmington deposit is, in my opinion, late Pleistocene, and may be similar in age to the raised marine deposits of the Durham littoral and contemporaneous with some of the leafy and other clays of the Tyne Valley, etc. The evidence does not appear to be sufficient to prove the Kirmington deposit to be an Interylacial (or even an Interval) deposit, see Lamplugh, "The Interglacial Problem in the British Isles": Inlernational Geological Congress, Canada, 1913, p. 3.

2 Geology in the Field, p. 175.

3 Woodward's Geol. of England and Wales, p. 555 .

4 e.g. the Brown clay, Common clay, ete., of the Tyne valley. 
Valley during the formation of these deposits, but there is clear proof that a fauna of this type existed while the leafy clays (already noticed, p. 70) of a somewhat similar age were being deposited at Kirmington (Lines.). The mollusca there include Scrobicularia. piperata, Cardium edule, Mytilus edulis, Tellina balthica (B. A. Report, 1904, p. 273). I do not, however, propose to discuss the extent, thickness, and character of these estuarine deposits in the Tyne-Wear region until the higher Raised Beach has been as definitely proved as the Easington one, and the results of Merrick's study of these deposits published.

There is much evidence which, in my opinion, is quite definite and sufficient, but which might be more fully investigated for the occurrence of late Pleistocene marine and estuarine deposits up to 140-50 feet in north-east Durham, of a slightly later age than the Easington Raised Beach. ${ }^{1}$ It includes (1) a cave at Marsden, (2) a cliff with bedded deposits, containing shells and shell fragments resting against it on Fulwell and Cleadon Hills, (3) apparently wave-worn rock surfaces on which the deposits rest, (4) shell-bearing gravels and sands which are distinct from the Kames and Fluvio-glacial gravels and sands, (5) horizontally and current-bedded gravels and sands, (6) ripple-marked sands, and (7) extensive deposits of leafy and other clays. There are several sections in which portions of these deposits are exposed, but it is difficult to get one similar to that at Easington, which would indisputably prove their marine origin. Such sections have been described (as e.g. the exposure in Fulwell Quarries, which I examined during 1900-6), and it is hoped that one will soon be again. A critical examination of the series of exposures which can be seen at the present time would, however, be quite sufficient to settle conclusively that raised marine and estuarine deposits do occur up to 150 feet above sea-level along the Durham coastal region.

Adpendum I.-The Permian in the immediate neighbourhood of the Easington deposit is also very interesting. In the railway cutting above there is one of the best fossiliferous exposures of the Bryozoa Reef, which is replaced in the cliff by unfossiliferous bedded rocks and breccias, i.e. by its eastern equivalents (Fig. 1).

AdDendum II.--The general sequence of the Pleistocene and Recent deposits along the Durham coastal region is

1 The higher part of the Easington gravels (90 feet) may be contemporaneous with this 150 beach in north-east Durham. I stated in my paper on "The Superficial Deposits of the Northumberland and Durham Coalifield" (op. jam. cit., p. 75) that the course of cemented gravels of which the Easington deposit forms a part appears to rise very gradually from south to north. This observation, which now that these deposits are proved to be of littoral formation, is one worthy of investigation and surveying, as if it is correct, and due to the uplift only, it should not only be of value in considering the Pleistocene deposits of the Fast of England, but also in connexion with an important subject in theoretical geology, viz. that such changes of level as the Easington and similar formations prove were due to movements of the terrestrial crust and not to oscillations of the surface of the ocean (Sir A. Geikie, Q.J.G.S., vol. lx, 1904, p. cix). 
Dr. Woolacott-A Raised Beach in Durham.

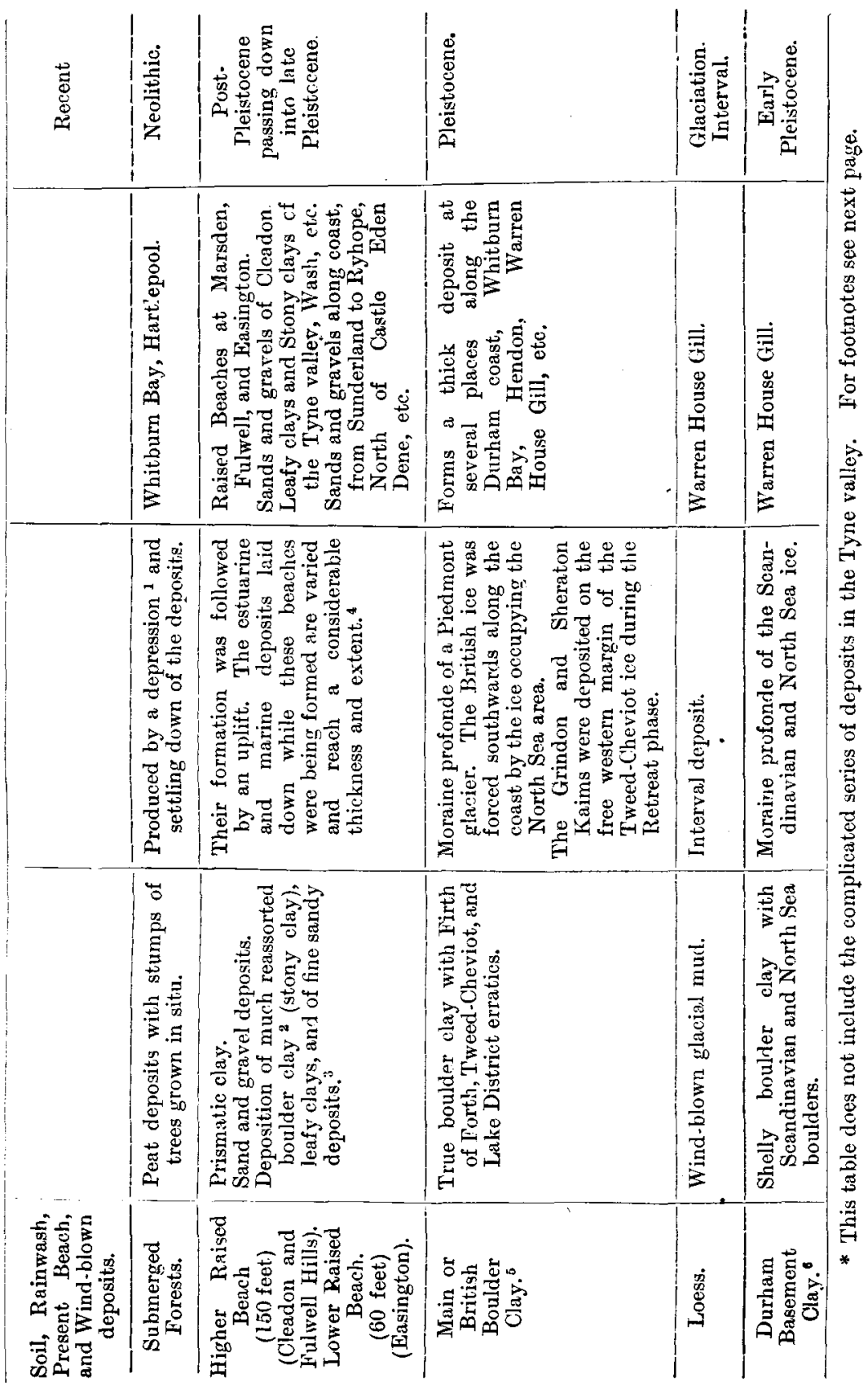




\title{
EXPLANATION OF PLATE $T$.
}

FIg. 1.-60-ft. Raised Beach at Easington. The section shown is about 6 feet in thickness and consists of bedded sands and gravels resting on a wave-cut platform of Magnesian Limestone. In a cutting which was made above the deposit the bedded cemented gravels and sands were proved to be 15 feet in thickness (on the face), overlaid by a few inches of loose shell-bearing sand, above which was reassorted boulder clay. The whole being covered by washed soil.

Fia. 2.-Photographs of cliffs at Easington, showing $60-\mathrm{ft}$. Raised Beach resting on rock shelf. The cliff is about 75 feet high. Along the part shown the beach rests on limestone, but the conrse of cemented gravels can be distinctly followed to the south, when it passes on to boulder clay. The platform becomes less uniform and distinet and the gravels thicken downwards. The top of the course, however, keeps on the same level. R. Raised Bearh. M. Middle Magnesian Limestoneeastern equivalents of the Reef which forms Beacon Hill immediately behind the coast at this point. (Fig. 3.)

\section{The Carboniferous Limestone Series of West Cumberland.}

\author{
By Charles Edmonds. \\ INTRODUCTION.
}

THE area under consideration extends from the mining town of 1 Egremont to Scalesmoor Farm in the parish of Lamplugh in West Cumberland, and comprises a tract of country 9 miles in length and rather less than 3 miles in width, running from S.S.W. to N.N.E. It forms the south-eastern margin of the Whitehaven Coalfield, and is the western portion of the "collar" of Lower Carboniferous rocks almost surrounding the older Palæozoic rocks of which the Lake District proper is composed. The area consists

\section{Notes to $p .73$.}

x Mr. E. Merrick informs me this depression can be definitely proved to have occurred.

2 Some of the clay with boulders (unstriated or occasionally striated) which is often called boulder-clay is not of direct Glacial origin, but is reassorted material. Another term should be used to distinguish it, perhaps "Stony clay" would do.

${ }_{3}$ This statement is true whether we accept the higher beach as proved or not, although in my opinion the extent and mode of occurrence of the leafy clays necessitate the existence of the higher beach. The formation of the beaches was contemporaneous with the deposition of stony and stoneless reassorted non-laminated clays and with leafy clays; and the uplift with extensive erosion of these and earlier Glacial and Fluvio-glacial beds. The Kirmington estuarine deposit was probably laid down at the same time as the leafy clays of the Tyne valley.

- I am of the opinion that the sea invaded the area as the ice was melting. The rafted boulders which have been dropped into the deposits were carried by floating ice (no remains of trees are found in the clays), and the contorted sands that sometimes occur (e.g. Ryhope) were probably produced by stranding ice-blocks.

5 Same as the Purple Clay of Yorkshire.

6 The Yorkshire Basement Clay is probably slightly later than the Durham. The evidence appears to prove that there was a Glaciation-Interval (Interglacial Period ?) between. 


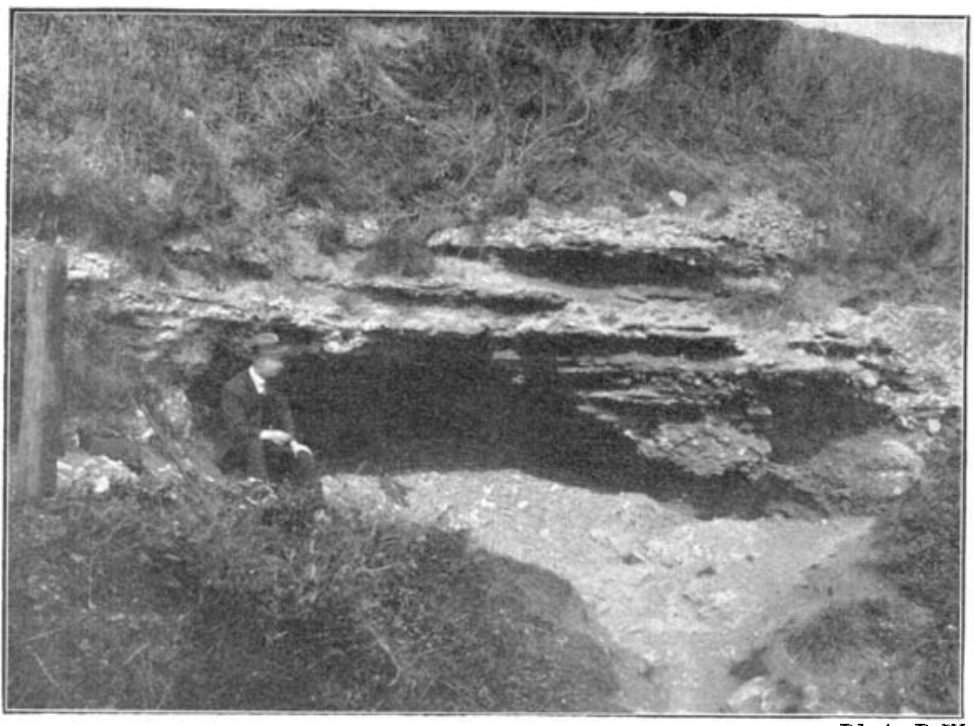

FIG. 1.-60 ft. Raised Beach at Easington.

Photo D.W.

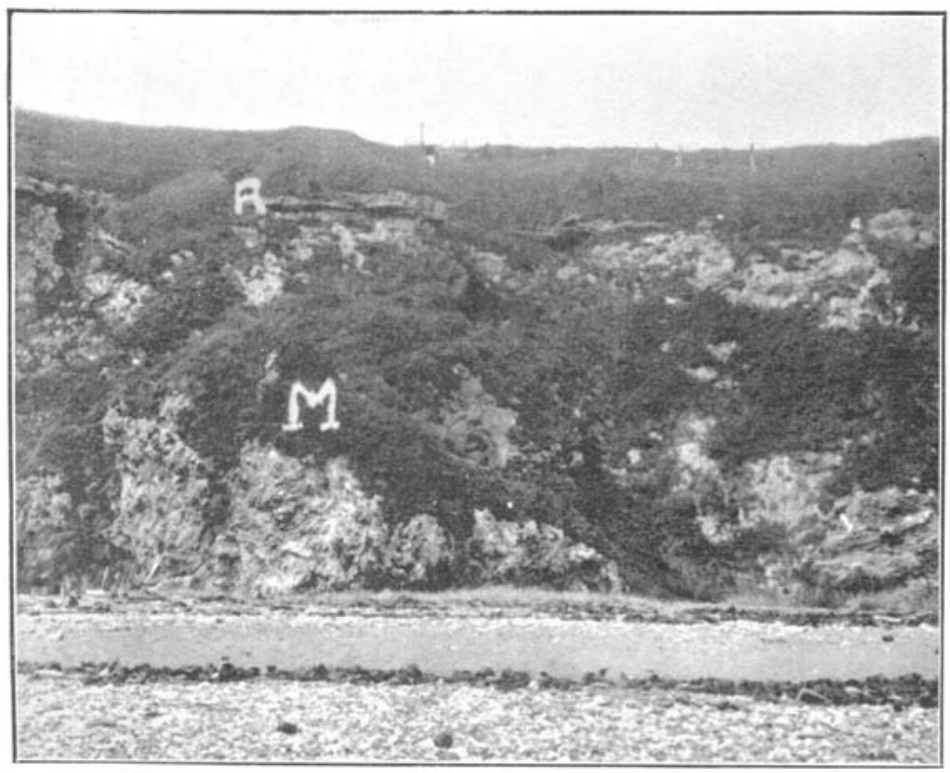

Photo D.W

FIG. 2.-Photograph of eliff at Easington showing $60 \mathrm{ft}$. Raised Beach resting on rock shelf.

[T'oface $p$. it. 